\title{
Effects of antioxidants and MAPK inhibitors on cell death and reactive oxygen species levels in $\mathrm{H}_{2} \mathrm{O}_{2}$-treated human pulmonary fibroblasts
}

\author{
WOO HYUN PARK \\ Department of Physiology, Medical School, Research Institute for Endocrine Sciences, \\ Chonbuk National University, JeonJu, Jeollabuk-do 561-180, Republic of Korea
}

Received November 28, 2012; Accepted February 25, 2013

DOI: $10.3892 / \mathrm{ol} .2013 .1216$

\begin{abstract}
H}_{2} \mathrm{O}_{2}$-induced cytotoxicity in normal human pulmonary fibroblasts (HPFs) is of interest in toxicological research since HPFs are involved in lung inflammation, fibrosis and cancer. The present study investigated the cytotoxic effects of $\mathrm{H}_{2} \mathrm{O}_{2}$ on normal HPFs in relation to reactive oxygen species (ROS) and mitogen-activated protein kinases (MAPKs) using the well-known antioxidants $\mathrm{N}$-acetyl cysteine (NAC) and propyl gallate (PG), as well as MAPK inhibitors. Treatment with $50 \mu \mathrm{M} \mathrm{H}_{2} \mathrm{O}_{2}$ inhibited the growth of the HPFs by $\sim 45 \%$ in $24 \mathrm{~h} . \mathrm{H}_{2} \mathrm{O}_{2}$ induced cell death via apoptosis and triggered the loss of mitochondrial membrane potential (MMP; $\Delta \psi_{\mathrm{m}}$ ) in the HPFs. $\mathrm{H}_{2} \mathrm{O}_{2}$ also increased the ROS levels, including $\mathrm{O}_{2}{ }^{--}$, in the HPFs and induced glutathione (GSH) depletion. NAC and PG attenuated the death of the HPFs and the loss of MMP $\left(\Delta \psi_{\mathrm{m}}\right)$ through the use of $\mathrm{H}_{2} \mathrm{O}_{2}$. NAC decreased the ROS levels in the $\mathrm{H}_{2} \mathrm{O}_{2}$-treated HPFs and PG markedly prevented an increase in $\mathrm{O}_{2}{ }^{--}$levels in these cells. However, PG alone induced cell death in the HPF control cells and increased the ROS levels in these cells. None of the MAPK (MEK, JNK and p38) inhibitors affected cell growth inhibition or cell death by $\mathrm{H}_{2} \mathrm{O}_{2}$. In addition,
\end{abstract}

Correspondence to: Professor Woo Hyun Park, Department of Physiology, Medical School, Research Institute for Endocrine Sciences, Chonbuk National University, San 2-20 Geumam-dong JeonJu, Jeollabuk-do 561-180, Republic of Korea

E-mail: parkwh71@chonbuk.ac.kr

Abbreviations: HPF, human pulmonary fibroblast; ROS, reactive oxygen species; MAPK, mitogen-activated protein kinase; MEK, MAP/ERK kinase; ERK, extracellular signal-regulated kinase; JNK, c-Jun N-terminal kinase; MMP $\left(\Delta \psi_{\mathrm{m}}\right)$, mitochondrial membrane potential; MTT, 3-(4,5-dimethylthiazol-2-yl)-2,5-diphenyltetrazolium bromide; FITC, fluorescein isothiocyanate; $\mathrm{H}_{2}$ DCFDA, 2',7'-dichlorodihydrofluorescein diacetate; DHE, dihydroethidium; GSH, glutathione; CMFDA, 5-chloromethylfluorescein diacetate; NAC, N-acetyl cysteine; PG, propyl gallate

Key words: human pulmonary fibroblasts, $\mathrm{H}_{2} \mathrm{O}_{2}$, cell death, reactive oxygen species, mitogen-activated protein kinase these inhibitors did not significantly affect the ROS levels and GSH depletion in the $\mathrm{H}_{2} \mathrm{O}_{2}$-treated HPFs. In conclusion, $\mathrm{H}_{2} \mathrm{O}_{2}$ induced growth inhibition and cell death in the HPFs via GSH depletion. NAC and PG attenuated $\mathrm{H}_{2} \mathrm{O}_{2}$-induced HPF cell death but each regulated the ROS levels in a different manner. Treatment with MAPK inhibitors did not affect cell death or the ROS levels in the $\mathrm{H}_{2} \mathrm{O}_{2}$-treated HPFs.

\section{Introduction}

Reactive oxygen species (ROS) are mainly comprised of hydrogen peroxide $\left(\mathrm{H}_{2} \mathrm{O}_{2}\right)$, superoxide anions $\left(\mathrm{O}_{2}{ }^{\circ}\right)$ and hydroxyl radicals $\left({ }^{\circ} \mathrm{OH}\right)$, which affect numerous cellular processes, including metabolism, differentiation and cell proliferation and death, by regulating critical signaling pathways (1,2). Unlike other $\mathrm{ROS}, \mathrm{H}_{2} \mathrm{O}_{2}$ is capable of freely diffusing through biological membranes the width of several cells prior to reacting with specific molecular targets. ROS are mostly generated during the process of mitochondrial respiration and by specific oxidases, including nicotine adenine diphosphate (NADPH) oxidase and xanthine oxidase (3). The main metabolic pathways use superoxide dismutases, which metabolize $\mathrm{O}_{2}{ }^{-*}$ to $\mathrm{H}_{2} \mathrm{O}_{2}$ (4). Further metabolism by catalase or glutathione (GSH) peroxidase yields $\mathrm{O}_{2}$ and $\mathrm{H}_{2} \mathrm{O}$ (5). Oxidative stress occurs through an increase in ROS levels and/or a decrease in cellular antioxidants, and leads to cell death (6-8). Exogenous $\mathrm{H}_{2} \mathrm{O}_{2}$ is frequently used as a representative ROS in modeling and inducing oxidative stress.

Three major groups of mitogen-activated protein kinases (MAPKs) exist: extracellular signal-regulated kinase (ERK1/2), c-Jun N-terminal kinase/stress-activated protein kinase (JNK/SAPK) and p38 (9). MAPKs are involved in crucial signaling pathways in cell proliferation, differentiation and cell death in response to various signals produced by growth factors, hormones and cytokines, as well as genotoxic and oxidative stressors $(9,10)$. Each MAPK pathway has comparatively varied upstream activators and unambiguous substrates (11). Abundant evidence has demonstrated that JNK and p38 are activated by ROS or mild oxidative shifts in the intracellular thiol/disulfide redox state, initiating processes associated with apoptosis $(12,13)$. ROS provoke ERK phosphorylation and also stimulate the ERK pathway (14). In the 
majority of instances, ERK activation has a pro-survival effect rather than a pro-apoptotic effect (15). In addition, MAPK pathways are also activated by the direct inhibition of MAPK phosphatases by the ROS. Since the differing and opposing effects on MAPKs are caused by various ROS in the cells, the correlation between ROS and MAPKs requires further clarification, particularly with regard to the signaling associated with cell survival and death.

Cultured normal human cells are invaluable biological models for mechanistic studies of oxidative stress. $\mathrm{H}_{2} \mathrm{O}_{2}$-induced cytotoxicity in normal fibroblast cells in vitro may be of interest in toxicological research with regard to the toxic potential of exogenous $\mathrm{H}_{2} \mathrm{O}_{2}$ in human pulmonary fibroblasts (HPFs) since HPFs are closely involved in lung inflammation, fibrosis and cancer. However, the toxicological mechanism of the effects of exogenous $\mathrm{H}_{2} \mathrm{O}_{2}$ on normal HPFs remains unknown with regard to MAPKs. The present study investigated the effects of the well-known antioxidants $\mathrm{N}$-acetyl cysteine (NAC) and propyl gallate (PG), as well as the MAPK inhibitors, on $\mathrm{H}_{2} \mathrm{O}_{2}$-treated HPFs in relation to cell growth and death and the ROS and GSH levels.

\section{Materials and methods}

Cell culture. HPFs purchased from PromoCell $\mathrm{GmbH}$ (Heidelberg, Germany) were maintained in a humidified incubator at $37^{\circ} \mathrm{C}$ with $5 \% \mathrm{CO}_{2}$. The HPFs were cultured in RPMI-1640 supplemented with $10 \%$ (v/v) fetal bovine serum (FBS) and $1 \%(\mathrm{v} / \mathrm{v})$ penicillin-streptomycin (GIBCO BRL, Grand Island, NY, USA). The HPFs were grown in 100-mm plastic tissue culture dishes (Nunc, Roskilde, Denmark) and harvested with trypsin-EDTA solution while in the logarithmic growth phase. The HPFs between passages four and eight were used. The study was approved by the Ethics Committee of Chonbuk National University, Jeonju, Republic of Korea.

Reagents. $\mathrm{H}_{2} \mathrm{O}_{2}$, NAC and $\mathrm{PG}$ were purchased from Sigma-Aldrich Chemical Company (St. Louis, MO, USA). The NAC was dissolved in buffer [20 mM HEPES (pH 7.0)], while the PG was dissolved in ethanol at $200 \mathrm{mM}$ as a stock solution. JNK inhibitors (SP600125), MEK inhibitors (PD98059) and p38 inhibitors (SB203580) were purchased from Calbiochem (San Diego, CA, USA). All the inhibitors were dissolved in DMSO at $10 \mathrm{mM}$ as stock solutions. The HPFs were pretreated with 2 mM NAC, $400 \mu \mathrm{M}$ PG or $10 \mu \mathrm{M}$ MAPK inhibitors for $1 \mathrm{~h}$ prior to treatment with $\mathrm{H}_{2} \mathrm{O}_{2}$. Ethanol $(0.2 \%)$ and DMSO $(0.2 \%)$ were used as control vehicles and did not affect cell growth or death.

Cell growth and cell number assays. The changes in cell growth in the HPFs were indirectly determined by measuring the 3-(4,5-dimethylthiazol-2-yl)-2,5-diphenyltetrazolium bromide (MTT; Sigma-Aldrich Chemical Company) dye absorbance. In brief, $4 \times 10^{4}$ cells per well were seeded in 96-well microtiter plates (Nunc). Following exposure to $50 \mu \mathrm{M}$ $\mathrm{H}_{2} \mathrm{O}_{2}$, with or without $2 \mathrm{mM}$ NAC, $400 \mu \mathrm{M}$ PG or $10 \mu \mathrm{M}$ MAPK inhibitors for $24 \mathrm{~h}, 20 \mu \mathrm{l}$ MTT solution $(2 \mathrm{mg} / \mathrm{ml}$ in PBS) was added to each well of the 96-well plates. The plates were incubated for an additional $4 \mathrm{~h}$ at $37^{\circ} \mathrm{C}$. The media in the plates were withdrawn by pipetting and $200 \mu 1$ DMSO was added to each well to solubilize the formazan crystals. The optical density was measured at $570 \mathrm{~nm}$ using a microplate reader (Synergy $^{\mathrm{TM}}$ 2; BioTek Instruments Inc., Winooski, VT, USA).

Annexin V-fluorescein isothiocyanate (FITC) staining for cell death detection. Apoptosis was determined by staining cells with annexin (Invitrogen Corporation, Camarillo, CA, USA; $\mathrm{Ex} / \mathrm{Em}=488 \mathrm{~nm} / 519 \mathrm{~nm})$. In brief, $1 \times 10^{6}$ cells were incubated in a 60-mm culture dish (Nunc) with $50 \mu \mathrm{M} \mathrm{H}_{2} \mathrm{O}_{2}$, with or without $2 \mathrm{mM}$ NAC, $400 \mu \mathrm{M}$ PG or $10 \mu \mathrm{M}$ MAPK inhibitors for $24 \mathrm{~h}$. The cells were washed twice with cold PBS, then resuspended in $500 \mu \mathrm{l}$ binding buffer $(10 \mathrm{mM} \mathrm{HEPES} / \mathrm{NaOH}$, $\mathrm{pH} 7.4 ; 140 \mathrm{mM} \mathrm{NaCl} ; 2.5 \mathrm{mM} \mathrm{CaCl}$ ) at a concentration of $1 \times 10^{6}$ cells/ml. Annexin V-FITC $(5 \mu \mathrm{l})$ was then added to the cells, which were analyzed with a FACStar flow cytometer (Becton Dickinson, Franklin Lakes, NJ, USA).

Measurement of mitochondrial membrane potential (MMP; $\left.\Delta \psi_{m}\right)$. MMP $\left(\Delta \psi_{\mathrm{m}}\right)$ levels were measured with a rhodamine 123 fluorescent dye (Sigma-Aldrich Chemical Company; $\mathrm{Ex} / \mathrm{Em}=485 \mathrm{~nm} / 535 \mathrm{~nm})$. In brief, $1 \times 10^{6}$ cells were incubated in a $60-\mathrm{mm}$ culture dish (Nunc) with $50 \mu \mathrm{M} \mathrm{H}_{2} \mathrm{O}_{2}$, with or without $2 \mathrm{mM}$ NAC, $400 \mu \mathrm{M}$ PG or $10 \mu \mathrm{M}$ MAPK inhibitors for $24 \mathrm{~h}$. The cells were washed twice with PBS and incubated with the rhodamine $123(0.1 \mu \mathrm{g} / \mathrm{ml})$ at $37^{\circ} \mathrm{C}$ for $30 \mathrm{~min}$. Rhodamine 123 staining intensity was determined with a FACStar flow cytometer (Becton Dickinson). Rhodamine 123-negative cells indicated the loss of MMP $\left(\Delta \psi_{\mathrm{m}}\right)$ in cells.

Detection of intracellular ROS levels. Intracellular ROS such as $\mathrm{H}_{2} \mathrm{O}_{2},{ }^{\circ} \mathrm{OH}$ and $\mathrm{ONOO}^{\circ}$ were detected using an oxidation-sensitive fluorescent probe dye, 2',7'-dichlorodihydrofluorescein diacetate $\left(\mathrm{H}_{2} \mathrm{DCFDA}\right.$; Ex/Em = $495 \mathrm{~nm} / 529 \mathrm{~nm}$; Invitrogen Molecular Probes, Eugene, OR, USA). $\mathrm{H}_{2}$ DCFDA is poorly selective for $\mathrm{O}_{2}{ }^{\circ}$. By contrast, dihydroethidium (DHE; $\mathrm{Ex} / \mathrm{Em}=518 \mathrm{~nm} / 605 \mathrm{~nm}$; Invitrogen Molecular Probes) is highly selective for $\mathrm{O}_{2}{ }^{--}$among all the ROS. In brief, $1 \times 10^{6}$ cells were incubated in a 60-mm culture dish (Nunc) with $50 \mu \mathrm{M}$ $\mathrm{H}_{2} \mathrm{O}_{2}$, with or without $2 \mathrm{mM}$ NAC, $400 \mu \mathrm{M}$ PG or $10 \mu \mathrm{M}$ MAPK inhibitors for $24 \mathrm{~h}$. The cells were then incubated with $20 \mu \mathrm{M} \mathrm{H}{ }_{2}$ DCFDA or dihydroethidium (DHE) at $37^{\circ} \mathrm{C}$ for $30 \mathrm{~min}$. The fluorescence of DCF and DHE was detected using a FACStar flow cytometer (Becton Dickinson). The ROS and $\mathrm{O}_{2}^{--}$levels were expressed as the mean fluorescence intensity (MFI), which was calculated by CellQuest software (Becton Dickinson).

Detection of the intracellular GSH. The cellular GSH levels were analyzed using a 5-chloromethylfluorescein diacetate dye (CMFDA, Ex/Em = 522 nm/595 nm; Invitrogen Molecular Probes). In brief, $1 \times 10^{6}$ cells were incubated in a $60-\mathrm{mm}$ culture

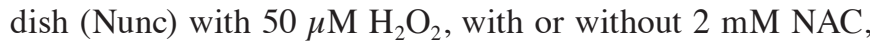
$400 \mu \mathrm{M}$ PG or $10 \mu \mathrm{M}$ MAPK inhibitors for $24 \mathrm{~h}$. The cells were then incubated with $5 \mu \mathrm{M}$ CMFDA at $37^{\circ} \mathrm{C}$ for $30 \mathrm{~min}$. The CMF fluorescence intensity was determined using a FACStar flow cytometer (Becton Dickinson). CMF-negative (GSH-depleted) cells were expressed as the percent of $\mathrm{CMF}^{-}$ cells. 

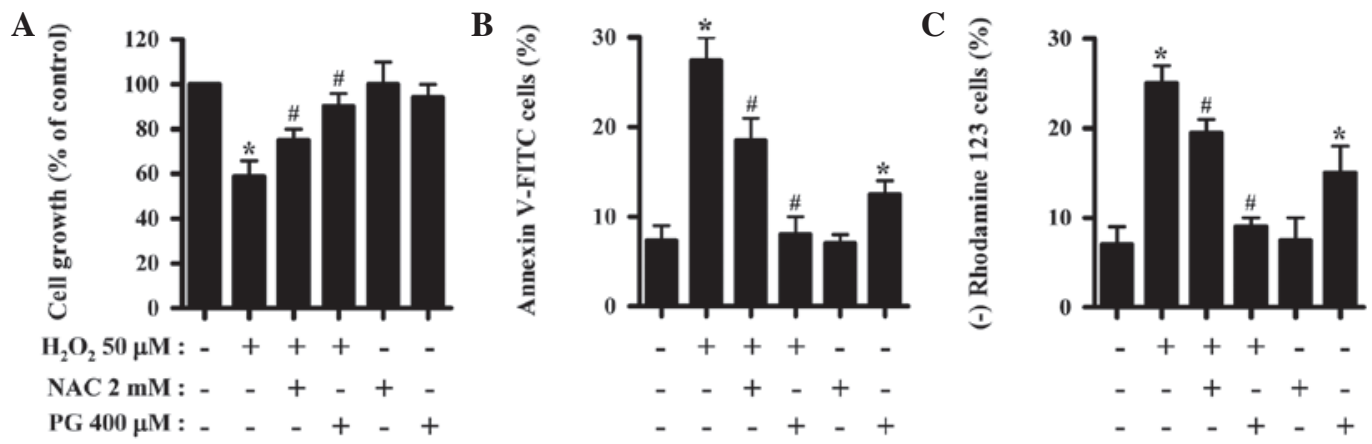

Figure 1. Effects of NAC and PG on cell growth and death and MMP $(\Delta \psi \mathrm{m})$ levels in the $\mathrm{H}_{2} \mathrm{O}_{2}$-treated HPFs. Exponentially-growing HPFs were treated with $50 \mu \mathrm{M} \mathrm{H}_{2} \mathrm{O}_{2}$ for $24 \mathrm{~h}$ following a $1 \mathrm{~h}$ pre-incubation with $2 \mathrm{mM} \mathrm{NAC}$ or $400 \mu \mathrm{M}$ PG. (A) Cellular growth changes in HPFs, as assessed by MTT assays. (B) Percentages of annexin V-FITC-positive cells, as measured by flow cytometry. (C) Percentages of rhodamine 123-negative $\left[\mathrm{MMP}\left(\Delta \psi_{\mathrm{m}}\right)\right.$ loss] cells. ${ }^{*} \mathrm{P}<0.05$ compared with the control group. ${ }^{*} \mathrm{P}<0.05$ compared with cells treated with $\mathrm{H}_{2} \mathrm{O}_{2}$ only. NAC, N-acetyl cysteine; PG, propyl gallate; MMP, mitochondrial membrane potential; HPF, human pulmonary fibroblast; MTT, 3-(4,5-dimethylthiazol-2-yl)-2,5-diphenyltetrazolium bromide; V-FITC, Annexin V-fluorescein isothiocyanate.
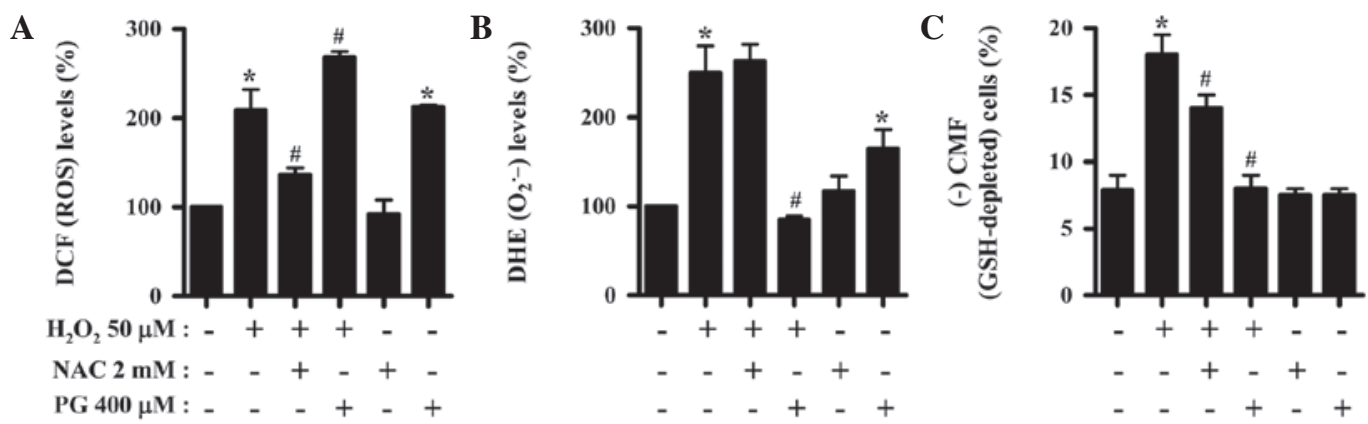

Figure 2. Effects of NAC and PG on intracellular ROS and GSH levels in $\mathrm{H}_{2} \mathrm{O}_{2}$-treated HPFs. Exponentially-growing $\mathrm{HPFs}$ were treated with $50 \mu \mathrm{M} \mathrm{H}_{2} \mathrm{O}_{2}$ for $24 \mathrm{~h}$ following a $1 \mathrm{~h}$ pre-incubation with $2 \mathrm{mM}$ NAC or $400 \mu \mathrm{M}$ PG. ROS levels in the HPFs were measured using a FACStar flow cytometer. (A) DCF (ROS) levels (\%) in the HPFs compared with the control cell group. (B) DHE $\left(\mathrm{O}_{2}^{\circ}\right)$ levels (\%) in the HPFs compared with the control cell group. (C) CMF (GSH-depleted) cells (\%) in the HPFs. " $\mathrm{P}<0.05$ compared with the control group. ${ }^{*} \mathrm{P}<0.05$ compared with cells treated with $\mathrm{H}_{2} \mathrm{O}_{2}$ only. NAC, $\mathrm{N}$-acetyl cysteine; PG, propyl gallate; ROS, reactive oxygen species; HPF, human pulmonary fibroblast; GSH, glutathione; DCF, 2',7'-dichlorodihydrofluorescein diacetate; DHE, dihydroethidium; CMF, 5-chloromethylfluorescein diacetate.

Statistical analysis. The results represent the mean of at least two independent experiments (mean \pm SD). The data were analyzed using Instat software (GraphPad Prism4; GraphPad Software, San Diego, CA, USA). The Student's t-test and a one-way analysis of variance (ANOVA) with post hoc analysis, using Tukey's multiple comparison, were applied to the parametric data. $\mathrm{P}<0.05$ was considered to indicate a statistically significant difference.

\section{Results}

Effects of NAC and $P G$ on cell growth and death and MMP $\left(\Delta \psi_{m}\right)$ levels in $\mathrm{H}_{2} \mathrm{O}_{2}$-treated HPFs. The effects of NAC and PG on cell growth and death and MMP $\left(\Delta \psi_{\mathrm{m}}\right)$ levels were investigated in $\mathrm{H}_{2} \mathrm{O}_{2}$-treated $\mathrm{HPFs}$ at $24 \mathrm{~h}$ using MTT assays. A concentration of $50 \mu \mathrm{M} \mathrm{H}_{2} \mathrm{O}_{2}$ was used as an optimal dose in this experiment; this inhibited the growth of the HPFs by $\sim 45 \%$ in 24 h (Fig. 1A). NAC and PG significantly reduced the growth inhibition caused by $\mathrm{H}_{2} \mathrm{O}_{2}$, with $\mathrm{PG}$ showing a more marked effect (Fig. 1A). $\mathrm{H}_{2} \mathrm{O}_{2}$ increased the percentage of annexin V-FITC stained cells among the HPFs, indirectly indicating that the HPF cell death caused by $\mathrm{H}_{2} \mathrm{O}_{2}$ occurred via apoptosis (Fig. 1B). NAC and PG significantly reduced the number of annexin V-FITC-positive cells in the $\mathrm{H}_{2} \mathrm{O}_{2}$-treated
HPFs, while PG completely prevented the HPF cell death caused by $\mathrm{H}_{2} \mathrm{O}_{2}$ (Fig. 1B). Notably, $\mathrm{PG}$ alone increased the number of annexin V-FITC-positive cells among the control HPFs (Fig. 1B). Since cell death is closely associated with the collapse of MMP $\left(\Delta \psi_{\mathrm{m}}\right)(16)$, the effect of $\mathrm{H}_{2} \mathrm{O}_{2}$ on MMP $\left(\Delta \psi_{\mathrm{m}}\right)$ in the HPFs was assessed using a rhodamine 123 dye. Treatment with $50 \mu \mathrm{M} \mathrm{H}_{2} \mathrm{O}_{2}$ significantly induced the loss of MMP $\left(\Delta \psi_{\mathrm{m}}\right)$ in the HPFs (Fig. 1C). NAC and PG attenuated the loss of MMP $\left(\Delta \psi_{\mathrm{m}}\right)$ caused by $\mathrm{H}_{2} \mathrm{O}_{2}$, while PG totally prevented this loss (Fig. 1C). Similar to the number of annexin V-FITC-positive cells, PG also increased the number of cells that lost MMP $\left(\Delta \psi_{\mathrm{m}}\right)$ among the control HPFs (Fig. 1C).

Effects of NAC and PG on intracellular ROS and GSH levels in $\mathrm{H}_{2} \mathrm{O}_{2}$-treated HPFs. $\mathrm{H}_{2}$ DCFDA and DHE dyes were used to assess intracellular ROS levels in the $\mathrm{H}_{2} \mathrm{O}_{2}$-treated HPFs. As shown in Fig. 2A, the levels of ROS (DCF), such as $\mathrm{H}_{2} \mathrm{O}_{2}$, were increased in the HPFs treated with $50 \mu \mathrm{M}$ at $24 \mathrm{~h}$. NAC significantly suppressed the increased ROS levels in the $\mathrm{H}_{2} \mathrm{O}_{2}$-treated HPFs, whereas PG enhanced the increase in ROS levels caused by $\mathrm{H}_{2} \mathrm{O}_{2}$ (Fig. 2A). Moreover, $\mathrm{PG}$ alone markedly increased the ROS (DCF) levels in the control HPFs (Fig. 2A). When the intracellular $\mathrm{O}_{2}{ }^{-}$levels were assessed in the $\mathrm{H}_{2} \mathrm{O}_{2}$-treated HPFs, the level of DHE fluorescence dye, which 

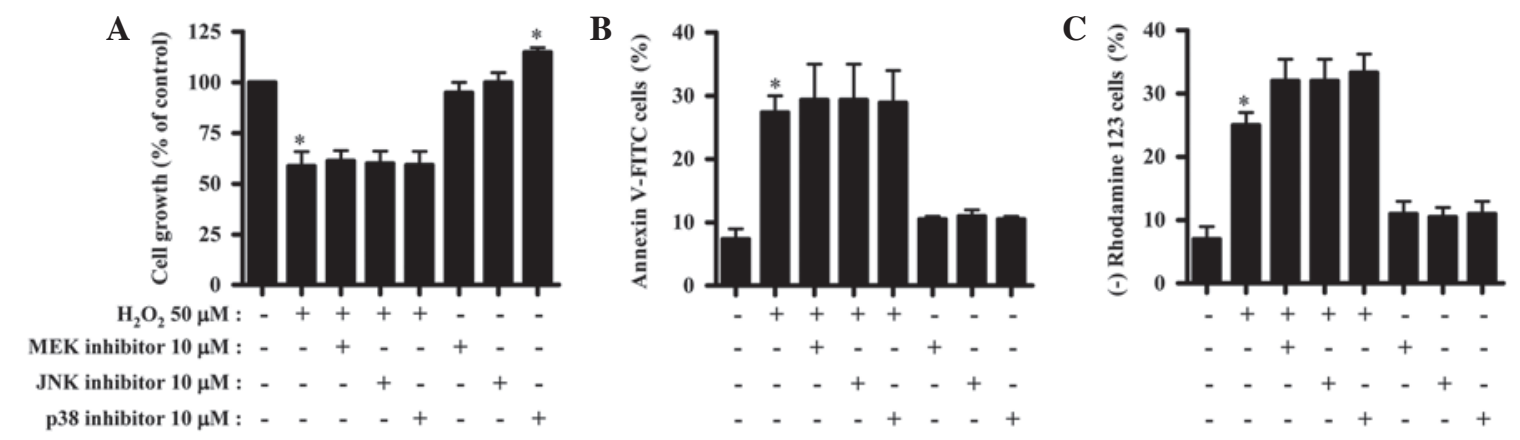

Figure 3. Effects of MAPK inhibitors on cell growth and death and MMP $(\Delta \psi \mathrm{m})$ levels in $\mathrm{H}_{2} \mathrm{O}_{2}$-treated HPFs. Exponentially-growing HPFs were treated with $50 \mu \mathrm{M} \mathrm{H}_{2} \mathrm{O}_{2}$ for $24 \mathrm{~h}$ following a $1 \mathrm{~h}$ pre-incubation with each MAPK inhibitor. (A) Cellular growth changes in the HPFs, as assessed by MTT assays. (B) Percentages of annexin V-FITC-positive cells, as measured by FACStar flow cytometry. (C) Percentages of rhodamine 123-negative [MMP $\left(\Delta \psi_{\mathrm{m}}\right)$ loss] cells. " $\mathrm{P}<0.05$ compared with the control group. ${ }^{*} \mathrm{P}<0.05$ compared with cells treated with $\mathrm{H}_{2} \mathrm{O}_{2}$ only. MAPK, mitogen-activated protein kinase; MEK, MAP/ERK kinase; JNK, c-Jun N-terminal kinase; MMP, mitochondrial membrane potential; HPF, human pulmonary fibroblast; MTT, 3-(4,5-dimethylthiazol-2-yl)-2,5-diphenyltetrazolium bromide; V-FITC, Annexin V-fluorescein isothiocyanate.
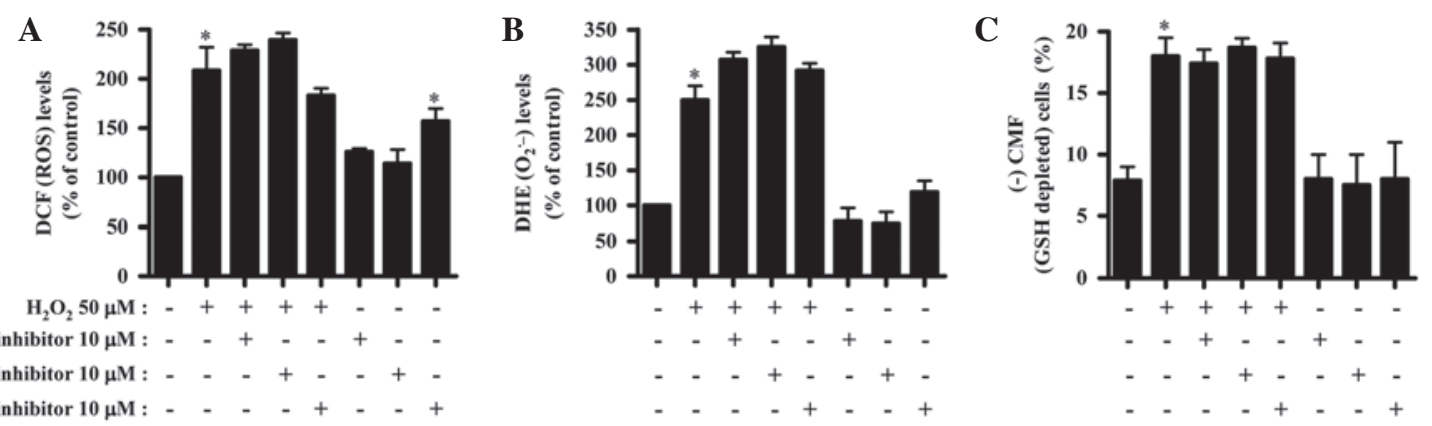

Figure 4. Effects of MAPK inhibitors on intracellular ROS and GSH levels in $\mathrm{H}_{2} \mathrm{O}_{2}$-treated HPFs. Exponentially-growing HPFs were treated with $50 \mu \mathrm{M}$ $\mathrm{H}_{2} \mathrm{O}_{2}$ for $24 \mathrm{~h}$ following a $1 \mathrm{~h}$ pre-incubation with each MAPK inhibitor. ROS levels in the HPFs were measured using a FACStar flow cytometer. (A) DCF (ROS) levels (\%) in the HPFs compared with the control cell group. (B) DHE $\left(\mathrm{O}_{2}^{\circ}\right)$ levels (\%) in the HPFs compared with the control cell group. (C) CMF(GSH-depleted) cells (\%) in the HPFs. ${ }^{*} \mathrm{P}<0.05$ compared with the control group. ${ }^{*} \mathrm{P}<0.05$ compared with cells treated with $\mathrm{H}_{2} \mathrm{O}_{2}$ only. MAPK, mitogen-activated protein kinase; MEK, MAP/ERK kinase; JNK, c-Jun N-terminal kinase; ROS, reactive oxygen species; HPF, human pulmonary fibroblast; GSH, glutathione; DCF, 2',7'-dichlorodihydrofluorescein diacetate; DHE, dihydroethidium; CMF, 5-chloromethylfluorescein diacetate.

specifically indicates $\mathrm{O}_{2}{ }^{-}$accumulation in cells, was increased at $24 \mathrm{~h}$ (Fig. 2B). While NAC did not alter the $\mathrm{O}_{2}^{-{ }^{-}}$level in the $\mathrm{H}_{2} \mathrm{O}_{2}$-treated $\mathrm{HPFs}, \mathrm{PG}$ entirely attenuated the increase in these cells (Fig. 2B). However, PG alone increased the $\mathrm{O}_{2}{ }^{-}$level in the control HPFs (Fig. 2B). When the intracellular GSH levels were measured in the $\mathrm{H}_{2} \mathrm{O}_{2}$-treated HPFs using a CMFDA dye, $50 \mu \mathrm{M} \mathrm{H}_{2} \mathrm{O}_{2}$ was shown to increase the number of GSH-depleted cells in the HPFs at $24 \mathrm{~h}$ (Fig. 2C). NAC and PG significantly reduced the number of GSH-depleted cells in the $\mathrm{H}_{2} \mathrm{O}_{2}$-treated $\mathrm{HPFs}$, while PG completely prevented the GSH depletion (Fig. 2C).

Effects of MAPK inhibitors on cell growth and death and $M M P\left(\Delta \psi_{m}\right)$ levels in $\mathrm{H}_{2} \mathrm{O}_{2}$-treated HPFs. The effect of the MAPK inhibitors on cell growth and death and MMP $\left(\Delta \psi_{\mathrm{m}}\right)$ levels in the $\mathrm{H}_{2} \mathrm{O}_{2}$-treated HPFs was evaluated. Based on previous studies $(17,18), 10 \mu \mathrm{M}$ of each MAPK inhibitor was used as an optimal dose in the present study. None of the MAPK inhibitors affected the growth inhibition caused by $\mathrm{H}_{2} \mathrm{O}_{2}$ (Fig. 3A). p38 inhibitor alone increased the growth of control HPFs (Fig. 3A). Additionally, none of the MAPK inhibitors affected the number of annexin $\mathrm{V}$-stained cells among the $\mathrm{H}_{2} \mathrm{O}_{2}$-treated or -untreated HPFs (Fig. 3B). All the
MAPK inhibitors appeared to enhance the loss of MMP $\left(\Delta \psi_{\mathrm{m}}\right)$ in the $\mathrm{H}_{2} \mathrm{O}_{2}$-treated HPFs (Fig. 3C).

Effects of MAPK inhibitors on intracellular ROS and GSH levels in $\mathrm{H}_{2} \mathrm{O}_{2}$-treated $\mathrm{HPFs}$. The changes in intracellular ROS levels in the $\mathrm{H}_{2} \mathrm{O}_{2}$ and/or each MAPK inhibitor-treated HPF were assessed. As shown in Fig. 4A, the MEK and JNK inhibitors only marginally enhanced the ROS levels in the $\mathrm{H}_{2} \mathrm{O}_{2}$-treated $\mathrm{HPFs}$, whereas the p38 inhibitor appeared to decrease the ROS levels (Fig. 4A). In addition, all the MAPK inhibitors marginally intensified the $\mathrm{O}_{2}{ }^{-1}$ level increase caused by $\mathrm{H}_{2} \mathrm{O}_{2}$ (Fig. 4B). The p38 inhibitor alone increased the ROS levels, including the $\mathrm{O}_{2}^{-{ }^{-}}$level, in the HPF control cells (Fig. 4A and B). Moreover, none of the MAPK inhibitors affected the number of GSH-depleted cells in the $\mathrm{H}_{2} \mathrm{O}_{2}$-treated or untreated HPFs (Fig. 4C).

\section{Discussion}

HPFs are pathophysiologically involved in lung inflammation, fibrosis and cancer since these cells synthesize extracellular matrix and collagen to maintain the structural and functional integrity of the lung. The present study focused on elucidating 
the cytotoxic effect of exogenous $\mathrm{H}_{2} \mathrm{O}_{2}$ on cell growth and death in normal HPFs, in relation to ROS and MAPKs. Treatment with $50 \mu \mathrm{M} \mathrm{H}_{2} \mathrm{O}_{2}$ inhibited the growth of HPFs by $\sim 45 \%$ in $24 \mathrm{~h} . \mathrm{H}_{2} \mathrm{O}_{2}$ increased the number of annexin V-FITC-positive cells among the HPFs, indicating that $\mathrm{H}_{2} \mathrm{O}_{2}$-induced HPF cell death occurred via apoptosis. An increase in caspase-3 activity was also observed in the $\mathrm{H}_{2} \mathrm{O}_{2}$-treated HPFs (data not shown). In addition, $\mathrm{H}_{2} \mathrm{O}_{2}$ triggered the loss of $\mathrm{MMP}\left(\Delta \psi_{\mathrm{m}}\right)$ in the HPFs. The level cells with MMP $\left(\Delta \psi_{\mathrm{m}}\right)$ loss appeared to be similar to that of the annexin $\mathrm{V}$ stained cells, suggesting that cell death caused by $\mathrm{H}_{2} \mathrm{O}_{2}$ was markedly correlated with the collapse of MMP $\left(\Delta \psi_{\mathrm{m}}\right)$.

ROS toxicity in cells is generally mediated by ${ }^{\circ} \mathrm{OH}(19)$. $\mathrm{H}_{2} \mathrm{O}_{2}$ and $\mathrm{O}_{2}{ }^{-}$are the main ROS involved in the cell signaling pathways. According to the present results, the ROS levels, including those of $\mathrm{O}_{2}{ }^{-}$, were significantly increased in the $\mathrm{HPFs}$ treated with $\mathrm{H}_{2} \mathrm{O}_{2}$. Since $50 \mu \mathrm{M} \mathrm{H}_{2} \mathrm{O}_{2}$ induced cell death and MMP $\left(\Delta \psi_{\mathrm{m}}\right)$ loss in the HPFs, it is possible that exogenous $\mathrm{H}_{2} \mathrm{O}_{2}$ generates $\mathrm{O}_{2}^{--}$by damaging the mitochondria and that $\mathrm{H}_{2} \mathrm{O}_{2}$ and $\mathrm{O}_{2}{ }^{--}$may be efficiently converted into toxic ${ }^{\circ} \mathrm{OH}$ via the Fenton reaction, resulting in the death of the HPFs. It is also possible that $\mathrm{H}_{2} \mathrm{O}_{2}$ activates oxidases, such as NADPH oxidase and xanthine oxidase, in HPFs to generate $\mathrm{O}_{2}{ }^{\circ}$. In th epresent study, NAC attenuated the growth inhibition and cell death of the $\mathrm{H}_{2} \mathrm{O}_{2}$-treated HPFs and also significantly attenuated the $\operatorname{MMP}\left(\Delta \psi_{\mathrm{m}}\right)$ loss in these cells. NAC markedly decreased the ROS (DCF) levels in the $\mathrm{H}_{2} \mathrm{O}_{2}$-treated HPFs. However, NAC did not reduce the increased $\mathrm{O}_{2}^{\circ-}$ (DHE) level caused by $\mathrm{H}_{2} \mathrm{O}_{2}$, suggesting that NAC did not block the $\mathrm{O}_{2}{ }^{--}$generation pathway induced by exogenous $\mathrm{H}_{2} \mathrm{O}_{2}$. In addition, the $\mathrm{O}_{2}{ }^{--}$level in the HPFs co-treated with $\mathrm{H}_{2} \mathrm{O}_{2}$ and NAC did not appear to be correlated with HPF cell death.

PG, as a synthetic antioxidant, exerts a variety of effects on tissues and cells. For example, PG is an efficient protector of liver cells against lipid peroxidation by oxygen radicals (20). By contrast, PG has pro-oxidant properties $(21,22)$. The antioxidative and cytoprotective properties of PG may change to pro-oxidative, cytotoxic and genotoxic properties in the presence of $\mathrm{Cu}(\mathrm{II})$ (23). The present results demonstrated that PG alone marginally inhibited the growth of the HPFs and induced cell death accompanied by the loss of MMP $\left(\Delta \psi_{\mathrm{m}}\right)$. In addition, PG increased the ROS levels, including those of $\mathrm{O}_{2}{ }^{-}$, in the HPFs. Thus, it is possible that PG, as a pro-oxidant, is able to directly generate mitochondrial $\mathrm{O}_{2}^{-}$in the HPFs by impairing mitochondrial function, consequently leading to HPF cell death via oxidative stress. Similarly, it has been reported that PG causes cytotoxic effects in isolated rat hepatocytes by causing mitochondrial damage (24) and that it also increases mitochondrial $\mathrm{O}_{2}{ }^{--}$levels in $\mathrm{HeLa}$ cells (25). Notably, PG markedly attenuated the growth inhibition and cell death in the $\mathrm{H}_{2} \mathrm{O}_{2}$-treated $\mathrm{HPFs}$ and also prevented MMP $\left(\Delta \psi_{\mathrm{m}}\right)$ loss in these cells. Moreover, PG completely abrogated the $\mathrm{O}_{2}{ }^{--}$(DHE) level increase caused by $\mathrm{H}_{2} \mathrm{O}_{2}$. Therefore, $\mathrm{PG}$ appeared to protect the HPFs against exogenous $\mathrm{H}_{2} \mathrm{O}_{2}$ by protecting the mitochondria. However, PG increased the ROS (DCF) levels in the $\mathrm{H}_{2} \mathrm{O}_{2}$-treated HPFs. Numerous studies, including the present study, support the hypothesis that PG has a role as an antioxidant $(20,26,27)$ or as a pro-oxidant $(21,22)$, depending on various conditions, such as the cell culture media, the co-treated drugs and the cell types. PG is likely to have differing effects on the levels of the different ROS in the cells. Further studies are required to elucidate the exact roles of the types of ROS in PG-treated HPFs.

In the present study, the MEK inhibitor, which is likely to inactivate ERK, did not affect growth inhibition or cell death in the $\mathrm{H}_{2} \mathrm{O}_{2}$-treated HPFs. Thus, $\mathrm{H}_{2} \mathrm{O}_{2}$ did not directly regulate the signaling associated with ERK in the HPFs to induce their growth inhibition and death. In addition, the JNK and p38 MAPKs, which are generally associated with cell death $(12,13)$, were not likely to be affected by $\mathrm{H}_{2} \mathrm{O}_{2}$ in the HPFs since none of the inhibitors affected the growth inhibition and cell death caused by $\mathrm{H}_{2} \mathrm{O}_{2}$. The p38 inhibitor alone increased the growth of the control HPFs, suggesting that p38 signaling is involved in the basal level of HPF growth. With regard to MMP $\left(\Delta \psi_{\mathrm{m}}\right)$, all the MAPK inhibitors marginally increased the loss of MMP $\left(\Delta \psi_{\mathrm{m}}\right)$ in the $\mathrm{H}_{2} \mathrm{O}_{2}$-treated HPFs, indicating that the dysregulation of these MAPK signalings enhanced the loss in these cells. Moreover, the MAPK inhibitors marginally, but not significantly, affected the ROS levels, including that of $\mathrm{O}_{2}{ }^{-}$, in the $\mathrm{H}_{2} \mathrm{O}_{2}$-treated HPFs. The p38 inhibitor increased the ROS levels in the HPF control cells regardless of the level of cell death, while the other inhibitors mildly affected the ROS levels, including that of $\mathrm{O}_{2}{ }^{-}$. Thus, the MAPK signalling in the $\mathrm{H}_{2} \mathrm{O}_{2}$-treated and -untreated HPFs did not meaningfully change the redox state to affect HPF death.

GSH is a key cellular non-protein antioxidant, which reduces $\mathrm{H}_{2} \mathrm{O}_{2}$ to $\mathrm{H}_{2} \mathrm{O}$ using $\mathrm{GSH}$ peroxidase (28). The intracellular GSH content has a significant effect on anticancer drug-induced apoptosis, indicating that apoptotic effects are inversely proportional to the GSH content $(29,30)$. Similarly, in the present study, $\mathrm{H}_{2} \mathrm{O}_{2}$ increased the number of GSH-depleted cells in the HPFs. NAC and PG demonstrated anti-apoptotic effects on the $\mathrm{H}_{2} \mathrm{O}_{2}$-treated HPFs, significantly suppressing the GSH depletion in these cells. In addition, none of the MAPK inhibitors affected the GSH depletion in the $\mathrm{H}_{2} \mathrm{O}_{2}$-treated HPFs. Therefore, the intracellular GSH content appears to be a decisive factor in HPF cell death. However, PG alone induced cell death in the HPF control cells but it did not significantly induce GSH depletion, suggesting that PG-induced HPF cell death is not highly associated with changes in the GSH level.

In conclusion, $\mathrm{H}_{2} \mathrm{O}_{2}$ induced growth inhibition and death in the HPFs via GSH depletion. NAC and PG attenuated $\mathrm{H}_{2} \mathrm{O}_{2}$-induced HPF cell growth inhibition and death, but each antioxidant affected the ROS levels, including that of $\mathrm{O}_{2}{ }^{--}$, differently in the $\mathrm{H}_{2} \mathrm{O}_{2}$-treated and -untreated HPFs. Treatment with MAPK inhibitors did not affect cell death or the ROS levels in the $\mathrm{H}_{2} \mathrm{O}_{2}$-treated HPFs. The present data provide useful information concerning the toxicological effect of exogenous $\mathrm{H}_{2} \mathrm{O}_{2}$ on normal HPFs with regard to ROS and MAPKs.

\section{Acknowledgements}

The present study was supported by a grant from the Ministry of Science and Technology (MoST)/Korea Science and Engineering Foundation (KOSEF) through the Diabetes Research Center at Chonbuk National University (2012-0009323). 


\section{References}

1. Gonzalez C, Sanz-Alfayate G, Agapito MT, Gomez-Niño A, Rocher A and Obeso A: Significance of ROS in oxygen sensing in cell systems with sensitivity to physiological hypoxia. Respir Physiol Neurobiol 132: 17-41, 2002.

2. Baran CP, Zeigler MM, Tridandapani S and Marsh CB: The role of ROS and RNS in regulating life and death of blood monocytes. Curr Pharm Des 10: 855-866, 2004.

3. Zorov DB, Juhaszova $M$ and Sollott SJ: Mitochondrial ROS-induced ROS release: an update and review. Biochim Biophys Acta 1757: 509-517, 2006.

4. Zelko IN, Mariani TJ and Folz RJ: Superoxide dismutase multigene family: a comparison of the CuZn-SOD (SOD1) Mn-SOD (SOD2), and EC-SOD (SOD3) gene structures, evolution, and expression. Free Radic Biol Med 33: 337-349, 2002.

5. Wilcox CS: Reactive oxygen species: roles in blood pressure and kidney function. Curr Hypertens Rep 4: 160-166, 2002.

6. Chen TJ, Jeng JY, Lin CW, Wu CY and Chen YC: Quercetin inhibition of ROS-dependent and -independent apoptosis in rat glioma C6 cells. Toxicology 223: 113-126, 2006.

7. Dasmahapatra G, Rahmani M, Dent P and Grant S: The tyrphostin adaphostin interacts synergistically with proteasome inhibitors to induce apoptosis in human leukemia cells through a reactive oxygen species (ROS)-dependent mechanism. Blood 107: 232-240, 2006.

8. Wallach-Dayan SB, Izbicki G, Cohen PY, Gerstl-Golan R, Fine A and Breuer R: Bleomycin initiates apoptosis of lung epithelia cells by ROS but not by Fas/FasL pathway. Am J Physiol Lung Cell Mol Physiol 290: L790-L796, 2006.

9. Genestra M: Oxyl radicals, redox-sensitive signalling cascades and antioxidants. Cell Signal 19: 1807-1819, 2007.

10. Blenis J: Signal transduction via the MAP kinases: proceed at your own RSK. Proc Natl Acad Sci USA 90: 5889-5892, 1993.

11. Kusuhara M, Takahashi E, Peterson TE, Abe J, Ishida M, Han J, Ulevitch R and Berk BC: p38 Kinase is a negative regulator of angiotensin II signal transduction in vascular smooth muscle cells: effects on $\mathrm{Na}^{+} / \mathrm{H}^{+}$exchange and ERK1/2. Circ Res 83: 824-831, 1998

12. Hsin YH, Chen CF, Huang S, Shih TS, Lai PS and Chueh PJ The apoptotic effect of nanosilver is mediated by a ROS- and JNK-dependent mechanism involving the mitochondrial pathway in NIH3T3 cells. Toxicol Lett 179: 130-139, 2008.

13. Mao X, Yu CR, Li WH and Li WX: Induction of apoptosis by shikonin through a ROS/JNK-mediated process in Bcr/Abl-positive chronic myelogenous leukemia (CML) cells. Cell Res 18: 879-888, 2008.

14. Guyton KZ, Liu Y, Gorospe M, Xu Q and Holbrook NJ: Activation of mitogen-activated protein kinase by $\mathrm{H}_{2} \mathrm{O}_{2}$. Role in cell survival following oxidant injury. J Biol Chem 271: 4138-4142, 1996.

15. Henson ES and Gibson SB: Surviving cell death through epidermal growth factor (EGF) signal transduction pathways: implications for cancer therapy. Cell Signal 18: 2089-2097, 2006.
16. Yang J, Liu X, Bhalla K, Kim CN, Ibrado AM, Cai J, Peng TI, Jones DP and Wang X: Prevention of apoptosis by Bcl-2: release of cytochrome c from mitochondria blocked. Science 275: 1129-1132, 1997.

17. Park WH: Mitogen-activated protein kinase inhibitors differently affect the growth inhibition and death of a proteasome inhibitor, MG132-treated human pulmonary fibroblast cells. Hum Exp Toxicol 30: 1945-1954, 2011.

18. Park WH: MAPK inhibitors and siRNAs differentially affect cell death and ROS levels in arsenic trioxide-treated human pulmonary fibroblast cells. Oncol Rep 27: 1611-1618, 2012.

19. Perez-Vizcaino F, Cogolludo A and Moreno L: Reactive oxygen species signaling in pulmonary vascular smooth muscle. Respir Physiol Neurobiol 174: 212-220, 2010.

20. Wu TW, Fung KP, Zeng LH, Wu J and Nakamura H: Propyl gallate as a hepatoprotector in vitro and in vivo. Biochem Pharmacol 48: 419-422, 1994.

21. Kobayashi H, Oikawa S, Hirakawa K and Kawanishi S: Metal-mediated oxidative damage to cellular and isolated DNA by gallic acid, a metabolite of antioxidant propyl gallate. Mutat Res 558: 111-120, 2004.

22. Kawanishi S, Oikawa S and Murata M: Evaluation for safety of antioxidant chemopreventive agents. Antioxid Redox Signal 7: 1728-1739, 2005

23. Jacobi H, Eicke B and Witte I: DNA strand break induction and enhanced cytotoxicity of propyl gallate in the presence of copper(II). Free Radic Biol Med 24: 972-978, 1998.

24. Nakagawa Y, Nakajima K, Tayama S and Moldéus P: Metabolism and cytotoxicity of propyl gallate in isolated rat hepatocytes: effects of a thiol reductant and an esterase inhibitor. Mol Pharmacol 47: 1021-1027, 1995.

25. Han YH and Park WH: Propyl gallate inhibits the growth of HeLa cells via regulating intracellular GSH level. Food Chem Toxicol 47: 2531-2538, 2009.

26. Reddan JR, Giblin FJ, Sevilla M, Padgaonkar V, Dziedzic DC, Leverenz VR, Misra IC, Chang JS and Pena JT: Propyl gallate is a superoxide dismutase mimic and protects cultured lens epithelial cells from $\mathrm{H}_{2} \mathrm{O}_{2}$ insult. Exp Eye Res 76: 49-59, 2003.

27. Chen $\mathrm{CH}$, Liu TZ, Chen $\mathrm{CH}$, Wong $\mathrm{CH}$, Chen $\mathrm{CH}$, Lu FJ and Chen SC: The efficacy of protective effects of tannic acid, gallic acid, ellagic acid, and propyl gallate against hydrogen peroxide-induced oxidative stress and DNA damages in IMR-90 cells. Mol Nutr Food Res 51: 962-968, 2007.

28. Rhee SG, Yang KS, Kang SW, Woo HA and Chang TS: Controlled elimination of intracellular $\mathrm{H}(2) \mathrm{O}(2)$ : regulation of peroxiredoxin, catalase, and glutathione peroxidase via post-translational modification. Antioxid Redox Signal 7: 619-626, 2005.

29. Estrela JM, Ortega A and Obrador E: Glutathione in cancer biology and therapy. Crit Rev Clin Lab Sci 43: 143-181, 2006

30. Higuchi Y: Glutathione depletion-induced chromosomal DNA fragmentation associated with apoptosis and necrosis. J Cell Mol Med 8: 455-464, 2004. 